\title{
Urinary excretion of B-group vitamins reflects the nutritional status of B-group vitamins in rats
}

\author{
Katsumi Shibata*, Chisa Sugita, Mitsue Sano and Tsutomu Fukuwatari \\ Department of Food Science and Nutrition, School of Human Cultures, The University of Shiga Prefecture, Hikone, Shiga 522-8533, Japan
}

(Received 25 June 2012 - Final revision received 18 October 2012 - Accepted 29 October 2012)

Journal of Nutritional Science (2013), vol. 2, e12, page 1 of 7

doi:10.1017/jns.2013.3

Abstract

We have reported previously that the urinary excretion of B-group vitamins reflects recent dietary intakes of these vitamins. We also proposed reference values for the urinary levels of B-group vitamins for human subjects, and used these for evaluating human nutritional status. However, the question arises as to whether the urinary excretion of B-group vitamins in animals or human subjects decreases immediately before they become B-group vitamin insufficient or when fed a diet low in vitamins. In the present study, rats were fed a vitamin-free diet for $5 \mathrm{~d}$, and changes in the levels of $\mathrm{B}$-group vitamins in urine and blood were monitored. Urinary excretion of vitamin $\mathrm{B}_{1}$, vitamin $\mathrm{B}_{2}$, 4-pyridoxic acid (a catabolite of vitamin $\mathrm{B}_{6}$ ), pantothenic acid, folate and biotin steeply decreased, and all of the values reached zero within 1-2 d. With respect to blood, the concentrations of only three of the eight B-group vitamins (vitamin $\mathrm{B}_{1}$, pyridoxal phosphate and biotin) decreased to $15 \%(P<0.0001), 7 \%(P<0.0001)$ and $2 \%(P<0.0001)$ on day 5 , respectively, compared with the values at the beginning of the experiment. The decrease was more rapid and the changes were greater in the urine samples than in the blood samples. The present data complement our previous proposal that the urinary excretion of B-group vitamins reflects the nutritional status of these vitamins.

Key words: Vitamins: Deficiency: Urine: Blood: Rats

The classical signs of severe deficiency are seldom observed with respect to B-group vitamins. Instead, an increase in non-specific symptoms, general morbidity and a loss of appetite related to impaired vitamin status are commonly seen. The aim of the present study was to determine a 'pre-sign' that can be observed before the appearance of an obvious vitamin deficiency such as beriberi, pellagra or ariboflavinosis. In general, vitamin deficiencies appear if vitamin intake is inadequate. However, these deficiencies can be caused by malabsorption and the reduced synthetic ability of coenzymes. Therefore, the classical assessment, which is undertaken by comparing the intakes of B-group vitamins with Dietary Reference Intakes ${ }^{(1-3)}$, is of limited effectiveness. Biochemical methods may be more suitable to use for assessment of B-group vitamin nutritional status. They include measuring, in erythrocytes, the activity of transketolase for vitamin $\mathrm{B}_{1}$ status $^{(4)}$, glutathione reductase for vitamin $\mathrm{B}_{2}$ status ${ }^{(5)}$, and aspartate aminotransferase and alanine aminotransferase for vitamin $\mathrm{B}_{6}$ status ${ }^{(6)}$. Measurement of the activities of these enzymes represents a functional test of the adequacies of vitamins $\mathrm{B}_{1}, \mathrm{~B}_{2}$ and $\mathrm{B}_{6}$. Relative enhancements of the activities of these enzymes by in vitro saturation with thiamine diphosphate $^{(7)}$, flavin adenine dinucleotide ${ }^{(8)}$ and pyridoxal phosphate $^{(6)}$ have been shown to be a sensitive and specific measurement for the detection and evaluation of these vitamins. Suitable biological methods are not available for the detection of other B-group vitamins such as niacin, pantothenic acid, folate, biotin and vitamin $\mathrm{B}_{12}$.

Inadequate intake of vitamins typically causes a reduction in the concentration of vitamins in the cells and body fluid. So far, the most commonly used procedure to assess the nutritional status of B-group vitamins has been measurement of the urinary levels of these vitamins ${ }^{(9-13)}$. Our research

Abbreviation: MW, molecular weight.

* Corresponding author: K. Shibata, fax +81 74928 8499, email kshibata@shc.usp.ac.jp

(C) The Author(s) 2013. The online version of this article is published within an Open Access environment subject to the conditions of the Creative Commons Attribution-NonCommercial-ShareAlike licence $<\mathrm{http}: / /$ creativecommons.org/licenses/by-nc-sa/2.5/>. The written permission of 
team $^{(14-21)}$ and other investigators ${ }^{(22-27)}$ have shown that the urinary excretion of B-group vitamins provides an indication of the recent dietary intakes of these vitamins. However, the questions remain as to whether the urinary excretion of B-group vitamins in animals and human subjects decreases immediately before they become B-group vitamin insufficient or when fed a diet low in vitamins.

In the present study, we investigated the changes in urinary excretion of water-soluble vitamins and those of blood and liver concentrations using rats fed a vitamin-free diet. Our findings suggest that a urine sample is the biological sample most suitable to use as a surrogate indicator of B-group vitamin insufficiency.

\section{Methods and materials}

\section{Ethical approval of study protocol}

The care and treatment of experimental animals conformed to the guidelines for the ethical treatment of laboratory animals set by The University of Shiga Prefecture (Shiga, Japan).

\section{Chemicals}

Vitamin-free milk casein, sucrose and L-methionine were purchased from Wako Pure Chemical Industries. Maize oil was purchased from Ajinomoto. Gelatinised maize starch, a mineral mixture (American Institute of Nutrition (AIN)-93G mineral mixture $)^{(28)}$, and a vitamin mixture (nicotinic acid-free AIN-93 vitamin mixture containing $25 \%$ choline bitartrate) ${ }^{(28)}$ were obtained from Oriental Yeast Co., Ltd.

Thiamine hydrochloride $\left(\mathrm{C}_{12} \mathrm{H}_{17} \mathrm{ClN}_{4} \mathrm{OS}\right.$ - $\mathrm{HCl}$; molecular weight $(M W)=337.27 \mathrm{Da})$, riboflavin $\left(\mathrm{C}_{17} \mathrm{H}_{20} \mathrm{~N}_{4} \mathrm{O}_{6} ; \mathrm{MW}=\right.$ $376.3 \mathrm{Da})$, pyridoxine hydrochloride $\left(\mathrm{C}_{8} \mathrm{H}_{11} \mathrm{NO}_{3}-\mathrm{HCl} ; \mathrm{MW}=\right.$ $205.63 \mathrm{Da})$, cyanocobalamin $\left(\mathrm{C}_{63} \mathrm{H}_{88} \mathrm{CoN}_{14} \mathrm{O}_{14} \mathrm{P} ; \mathrm{MW}=\right.$ $1355.40 \mathrm{Da})$, nicotinamide $\left(\mathrm{C}_{6} \mathrm{H}_{6} \mathrm{~N}_{2} \mathrm{O} ; \mathrm{MW}=122.13 \mathrm{Da}\right)$, calcium pantothenate $\left(\mathrm{C}_{18} \mathrm{H}_{32} \mathrm{~N}_{2} \mathrm{O}_{10}-\mathrm{Ca} ; \mathrm{MW}=476.54 \mathrm{Da}\right)$, folic acid $\left(\mathrm{C}_{19} \mathrm{H}_{19} \mathrm{~N}_{7} \mathrm{O}_{6} ; \quad \mathrm{MW}=441.40 \mathrm{Da}\right)$ and $\mathrm{D}(+)$-biotin $\left(\mathrm{C}_{10} \mathrm{H}_{16} \mathrm{~N}_{2} \mathrm{O}_{3} \mathrm{~S} ; \quad \mathrm{MW}=244.31 \mathrm{Da}\right)$ were purchased from Wako Pure Chemical Industries. 4-Pyridoxic acid $\left(\mathrm{C}_{8} \mathrm{H}_{9} \mathrm{NO}_{4}\right.$; $\mathrm{MW}=183 \cdot 16 \mathrm{Da})$ manufactured by ICN Pharmaceuticals was obtained through Wako Pure Chemical Industries.

$\mathrm{N}^{1}$-Methylnicotinamide chloride $\left(\mathrm{C}_{7} \mathrm{H}_{9} \mathrm{~N}_{2} \mathrm{O}-\mathrm{HCl} ; \mathrm{MW}=\right.$ 159.61 Da) was purchased from Tokyo Kasei Kogyo. $N^{1}$-Methyl-2-pyridone-5-carboxamide (2-Py, $\quad \mathrm{C}_{7} \mathrm{H}_{8} \mathrm{~N}_{2} \mathrm{O}_{2}$; $\mathrm{MW}=152 \cdot 15 \mathrm{Da})$ and $\mathrm{N}^{1}$-methyl-4-pyridone-3-carboxamide (4-Py, $\mathrm{C}_{7} \mathrm{H}_{8} \mathrm{~N}_{2} \mathrm{O}_{2} ; \mathrm{MW}=152 \cdot 15 \mathrm{Da}$ ) were synthesised employing the methods of Pullman \& Colowick ${ }^{(29)}$ and Shibata et al. ${ }^{(30)}$, respectively. All other chemicals used were of the highest purity available from commercial sources.

\section{Animals and treatment}

The room was maintained at about $22^{\circ} \mathrm{C}$ and at a humidity of about $60 \%$. A $12 \mathrm{~h}$ light-12 h dark cycle (06.00-18.00 hours/ 18.00-06.00) was employed.

To acclimatise them to a new environment, male Wistar rats (6 weeks old; CLEA Japan) were kept in individual rat metabolism cages (CT-10; CLEA Japan) and fed a control diet ad libitum
Table 1. Composition of the diets

\begin{tabular}{|c|c|c|}
\hline & $\begin{array}{l}\text { Control diet } \\
(\%)\end{array}$ & $\begin{array}{l}\text { Vitamin-free } \\
\text { diet }(\%)\end{array}$ \\
\hline Milk casein (vitamin-free) & $20 \cdot 0$ & $20 \cdot 0$ \\
\hline L-Methionine & 0.2 & 0.2 \\
\hline Gelatinised maize starch & $46 \cdot 9$ & $47 \cdot 9$ \\
\hline Sucrose & 23.4 & 23.4 \\
\hline Maize oil & $5 \cdot 0$ & $5 \cdot 0$ \\
\hline Mineral mixture (AIN-93-MX-G)* & 3.5 & 3.5 \\
\hline $\begin{array}{l}\text { Vitamin mixture (AIN-93-VX containing } \\
25 \% \text { choline bitarrate, nicotinic acid-free) }\end{array}$ & 1.0 & 0 \\
\hline
\end{tabular}

*The compositions of the mineral mixture and the vitamin mixture are described by Reeves ${ }^{(28)}$

(Table 1) for $7 \mathrm{~d}$. The rats were then divided into two groups. One group was fed a control diet and the other fed a vitaminfree diet (Table 1) for $5 \mathrm{~d}$. The start of the experiment was designated as the time when the diet was changed. Each day, $24 \mathrm{~h}$ urine samples were collected (09.00-09.00 hours) in amber bottles containing $1 \mathrm{ml}$ of $1 \mathrm{M}-\mathrm{HCl}$ and stored at $-25^{\circ} \mathrm{C}$ until use. Rats were killed at about 09.00 hours; blood was collected and livers (not perfused) were taken to measure the contents of B-group vitamins in the urine, liver and blood. The removed livers were preserved at $-25^{\circ} \mathrm{C}$ until use.

Measurement of levels of B-group vitamins in urine, liver and blood

Preparation and measurement of the extracts of B-group vitamins from urine and blood were as previously described $^{(14,31,32)}$.

Vitamin $B_{1}$. Frozen liver samples, about $0.5 \mathrm{~g}$, were thawed, minced, added to ten volumes of cold $5 \%$ TCA and homogenised in a blender (Waring). The acidified homogenate was centrifuged at $10000 \mathrm{~g}$ for $10 \mathrm{~min}$ at $4^{\circ} \mathrm{C}$. The supernatant was retained and used for the measurement of the levels of vitamin $\mathrm{B}_{1}{ }^{(33)}$.

Vitamin $B_{2}$. Frozen liver samples, about $0.5 \mathrm{~g}$, were thawed, minced, added to ten volumes of $50 \mathrm{mM}-\mathrm{KH}_{2} \mathrm{PO}_{4}-\mathrm{K}_{2} \mathrm{HPO}_{4}$ buffer ( $\mathrm{pH} 7 \cdot 0$ ) and homogenised in a blender. To a $0.1 \mathrm{ml}$ aliquot of the homogenate, $0.44 \mathrm{ml}$ of water and $0.26 \mathrm{ml}$ of $0.5 \mathrm{M}-\mathrm{H}_{2} \mathrm{SO}_{4}$ were added and kept at $80^{\circ} \mathrm{C}$ for $15 \mathrm{~min}$. After cooling, $0.2 \mathrm{ml}$ of $10 \%$ TCA were added and the mixture was centrifuged at $10000 \mathrm{~g}$ for $3 \mathrm{~min}$ at $4^{\circ} \mathrm{C}$. From the supernatant obtained, $0.2 \mathrm{ml}$ were withdrawn and added to $0.2 \mathrm{ml}$ of $1 \mathrm{M}-\mathrm{NaOH}$. The alkalised mixture was irradiated at a height of $20 \mathrm{~cm}$ from the liquid with two fluorescent lamps $(20 \mathrm{~W})$ for $30 \mathrm{~min}$ at room temperature. Then, 0.02 $\mathrm{ml}$ of glacial acetic acid were added to the mixture. The neutralised mixture was passed through a $0.45 \mu \mathrm{m}$ microfilter. The filtrate was injected directly into an HPLC system for measuring lumiflavin levels ${ }^{(34)}$.

Vitamin $B_{6}$. Frozen liver samples, about $0.5 \mathrm{~g}$, were thawed, minced, added to $90 \mathrm{ml}$ of $55 \mathrm{M}-\mathrm{HCl}$ and homogenised in a blender. The homogenate was autoclaved at $121^{\circ} \mathrm{C}$ for $3 \mathrm{~h}$ to convert vitamin $\mathrm{B}_{6}$ coenzyme to the free form of vitamin $\mathrm{B}_{6}$. After cooling, the mixture was adjusted to $\mathrm{pH} 5.0$ with $1 \mathrm{M}-\mathrm{NaOH}$ and then brought up to $100 \mathrm{ml}$ with water. The solution was filtered with qualitative filter number 2 
(Advantec). The filtrate was used for measuring levels of vitamin $\mathrm{B}_{6}$ as previously described ${ }^{(35)}$.

Vitamin $B_{12}$. Frozen liver samples, about $0.5 \mathrm{~g}$, were thawed, minced and then added to $2.5 \mathrm{ml}$ of 0.57 M-acetic acidsodium acetate buffer ( $\mathrm{pH} 4.5)$ plus $5 \mathrm{ml}$ of water and $0.1 \mathrm{ml}$ of $0.05 \% \mathrm{KCN}$. The suspension was homogenised in a blender. The homogenate was then put into a boiling water-bath for $5 \mathrm{~min}$. After cooling, $0.15 \mathrm{ml}$ of $10 \%$ metaphosphoric acid was added and brought up to $10 \mathrm{ml}$ with water. The solution was filtered with qualitative filter number

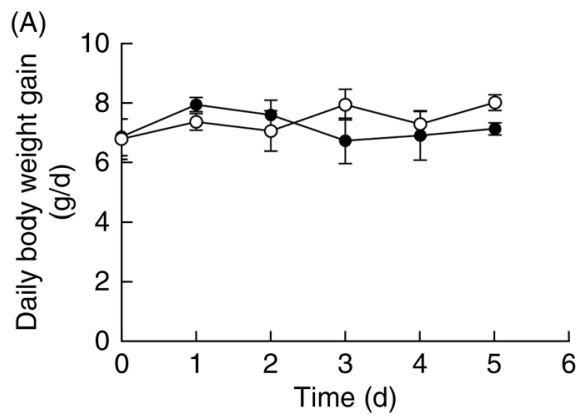

2 (Advantec). The filtrate was used for measuring levels of vitamin $\mathrm{B}_{12}$ as previously described ${ }^{(36)}$.

Nicotinamide. Frozen liver samples, about $0.6 \mathrm{~g}$, were thawed, minced and then added to five volumes of $0.1 \mathrm{~g} / \mathrm{ml}$ isonicotinamide. The suspension was then homogenised in a blender. The homogenate $(1 \mathrm{ml})$ was withdrawn, added to $4 \mathrm{ml}$ of water, and then autoclaved at $121^{\circ} \mathrm{C}$ for $10 \mathrm{~min}$ to convert pyridine nucleotide coenzymes to nicotinamide. After cooling, the mixture was centrifuged at $10000 \mathrm{~g}$ for $10 \mathrm{~min}$ at $4^{\circ} \mathrm{C}$. The supernatant was retained, the precipitated materials

(B)

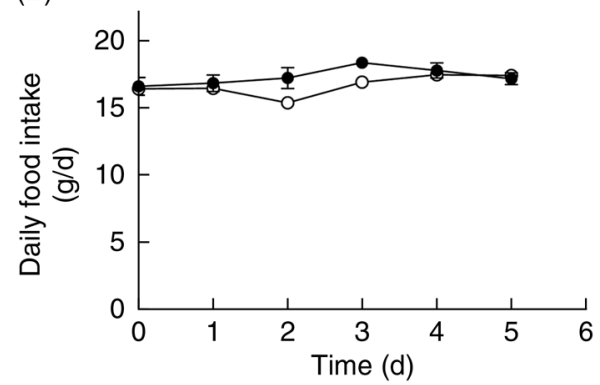

Fig. 1. Changes in body weight (A) and food intake (B) in male Wistar rats (aged 7 weeks) fed a vitamin-free diet $(\mathbf{O})$ or a control diet $(O)$ for 5 d. Values are means for five rats, with standard errors represented by vertical bars.

(A)

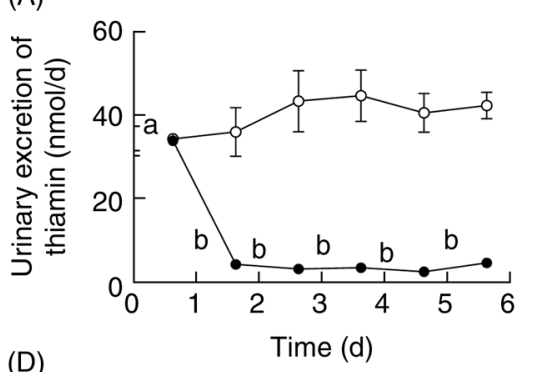

(D)

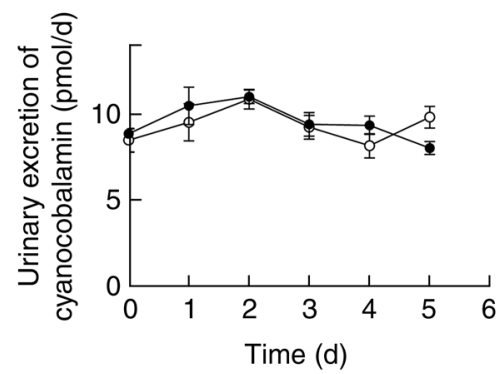

(G)

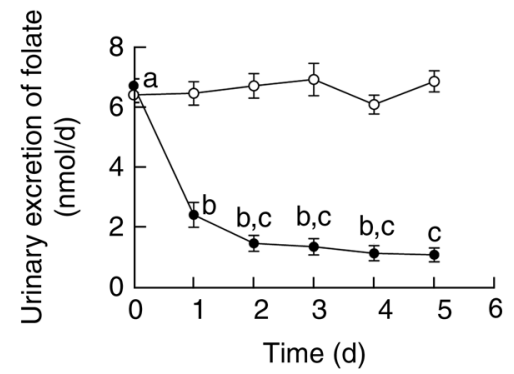

(B)

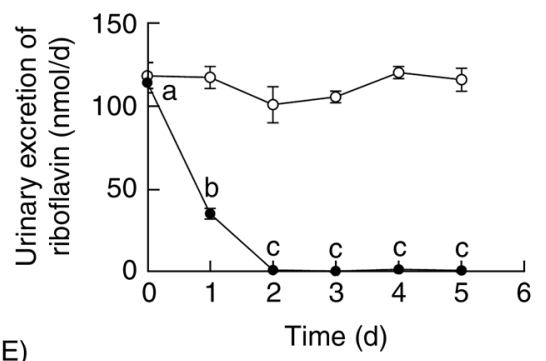

(E)

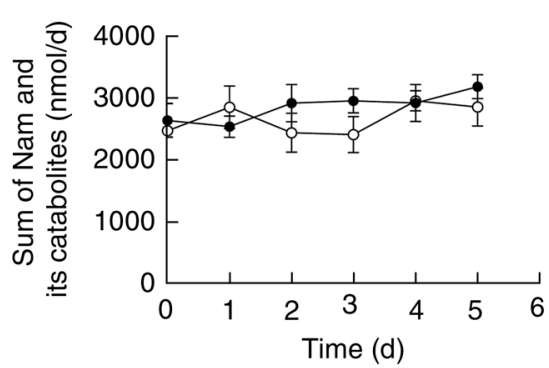

(H)

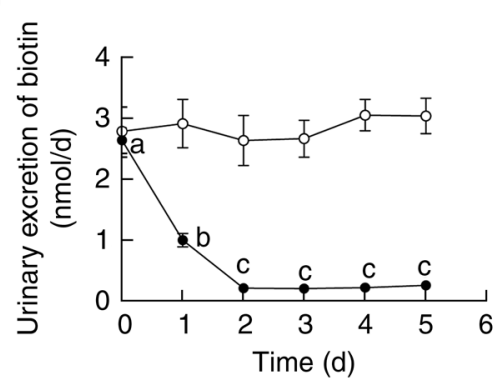

(C)
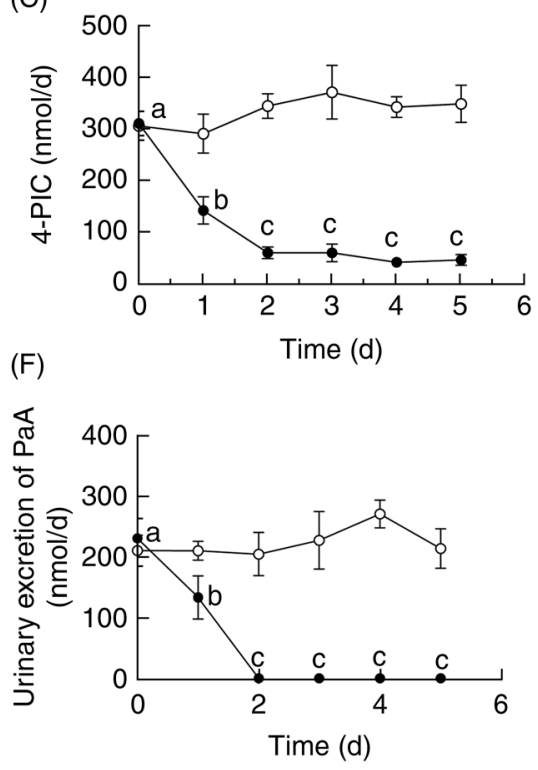

Fig. 2. Changes in the urinary excretion of thiamine (A), riboflavin (B), 4-pyridoxic acid (4-PIC) (C), vitamin $B_{12}$ (cyanocobalamin) (D), nicotinamide (Nam) and its metabolites $(E)$, pantothenic acid $(\mathrm{PaA})(\mathrm{F})$, folate $(\mathrm{G})$ and biotin $(\mathrm{H})$ in male Wistar rats (aged 7 weeks) fed a vitamin-free diet $(\mathbf{})$ or a control diet $(O)$ for $5 \mathrm{~d}$. Each day, 24 h urine samples (09.00-09.00 hours) were collected. Values are means for five rats, with standard errors represented by vertical bars. ${ }^{\text {a,b,c }}$ Mean values with unlike letters for the group fed the vitamin-free diet were significantly different $(P<0.05$; one-way ANOVA followed by Tukey's multiple-comparison tests). 
were extracted again with $5 \mathrm{ml}$ of water, and the resulting supernatant was retained. Both retained supernatants were combined and the extract was used for measuring nicotinamide levels as previously described ${ }^{(30)}$.

Pantothenic acid. Frozen liver samples, about $0.2 \mathrm{~g}$, were thawed, minced and then added to ten volumes of $50 \mathrm{~mm}-\mathrm{KH}_{2} \mathrm{PO}_{4}-\mathrm{K}_{2} \mathrm{HPO}_{4}$ buffer ( $\mathrm{pH}$ 7-0). The suspension was homogenised with a Teflon/glass homogeniser. The homogenate was incubated overnight at $37^{\circ} \mathrm{C}$ to convert free pantothenic acid from the bound type of pantothenate compounds. The reaction was stopped by placing the mixture into a boiling water-bath for $5 \mathrm{~min}$. After cooling, the mixture was centrifuged at $10000 \mathrm{~g}$ for $10 \mathrm{~min}$ at $4^{\circ} \mathrm{C}$. The supernatant was retained, the precipitated materials were extracted again with $2 \mathrm{ml}$ of water and the resulting supernatant retained. Both retained supernatants were combined, and the extract was used for measuring levels of pantothenic acid as previously described $^{(37)}$.

Folate. Frozen liver samples, about $0.5 \mathrm{~g}$, were thawed, minced and then added to ten volumes of $0.1 \mathrm{M}-\mathrm{KH}_{2} \mathrm{PO}_{4}-$ $\mathrm{K}_{2} \mathrm{HPO}_{4}$ buffer ( $\mathrm{pH}$ 6.1). The suspension was homogenised in a blender. The homogenate was autoclaved at $121^{\circ} \mathrm{C}$ for $5 \mathrm{~min}$. After cooling, $2.5 \mathrm{ml}$ of proteinase MS $(200 \mathrm{U} / \mathrm{ml}$ of water; Kaken Pharmaceutical Co., Ltd.) was added. The mixture was incubated at $37^{\circ} \mathrm{C}$ for $3 \mathrm{~h}$ to digest proteins and then release polyglutamated folates from the protein-bound types. The reaction was stopped by placing the mixture into a boiling water-bath for $10 \mathrm{~min}$. After cooling, $0.5 \mathrm{ml}$ of conjugase (extract from porcine kidney acetone powder (type II); Sigma-Aldrich) was added to the mixture and incubated overnight at $37^{\circ} \mathrm{C}$ to convert polyglutamated folates to monoglutamated folates. The reaction was stopped by placing the mixture in a boiling water-bath for $10 \mathrm{~min}$. After cooling, the mixture was centrifuged at $10000 \mathrm{~g}$ for $10 \mathrm{~min}$ at $4^{\circ} \mathrm{C}$. The supernatant was retained, the precipitated materials extracted again with $3 \mathrm{ml}$ of water, and the resulting supernatant retained. Both the retained supernatants were combined, and the extract was used for measuring folate levels as previously described ${ }^{(38)}$. The conjugase solution was made up as follows: $60 \mathrm{ml}$ of $50 \mathrm{~mm}-\mathrm{KH}_{2} \mathrm{PO}_{4}-\mathrm{K}_{2} \mathrm{HPO}_{4}$ buffer ( $\mathrm{pH} 7 \cdot 0$ ) was added to $20 \mathrm{~g}$ of porcine kidney acetone powder and stirred for $30 \mathrm{~min}$ at $4^{\circ} \mathrm{C}$. The suspension was centrifuged at $10000 \mathrm{~g}$ for $10 \mathrm{~min}$ at $4^{\circ} \mathrm{C}$. The supernatant was dialysed against a large amount of $50 \mathrm{~mm}-\mathrm{KH}_{2} \mathrm{PO}_{4}-\mathrm{K}_{2} \mathrm{HPO}_{4}$ buffer $(\mathrm{pH} 7 \cdot 0)$ to remove endogenous folate from the kidney acetone powder. The dialysed conjugase solution was used.
(A)

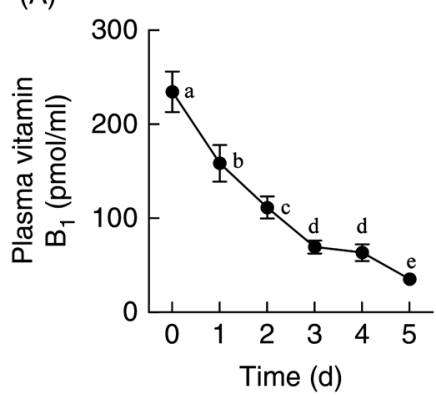

(D)

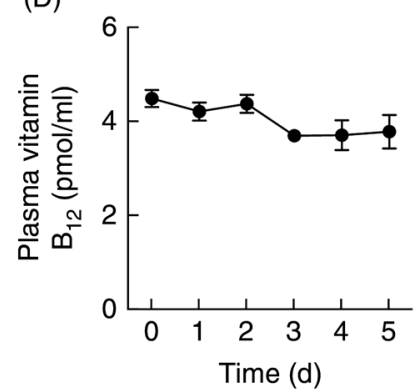

(G)

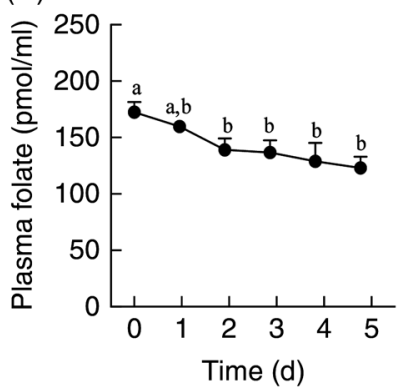

(B)

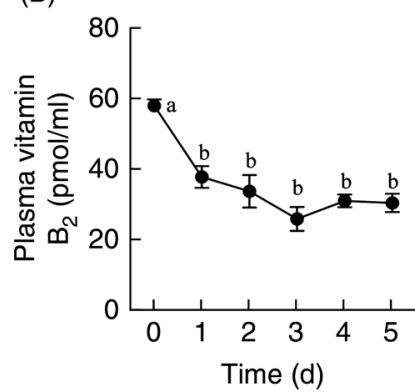

(E)

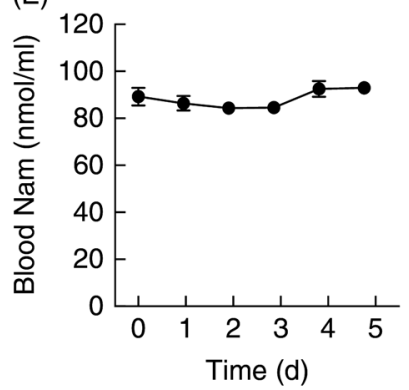

(H)

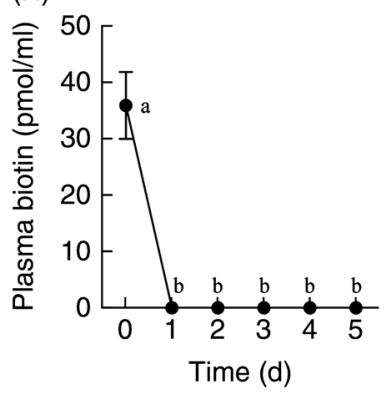

(C)

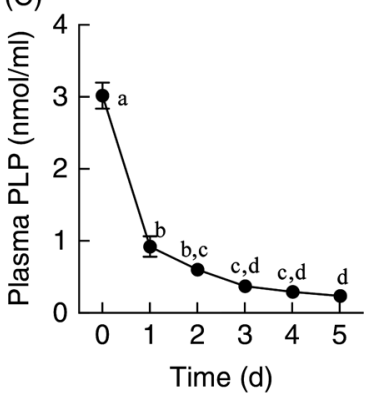

(F)

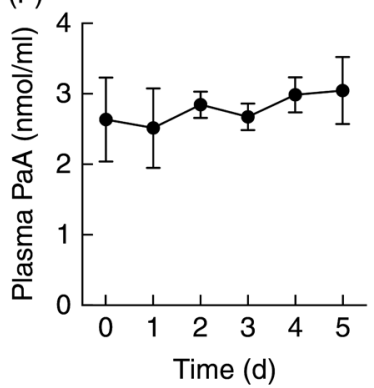

Fig. 3. Changes in the levels of vitamin $B_{1}(A)$, vitamin $B_{2}(B)$, pyridoxal phosphate $(P L P)(C)$, vitamin $B_{12}(D)$, nicotinamide $($ Nam) $(E)$, pantothenic acid (PaA) ( $)$, folate $(\mathrm{G})$ and biotin $(\mathrm{H})$ in the plasma or whole blood of male Wistar rats (aged 7 weeks) fed a vitamin-free diet for 5 d. Rats were killed each day and blood was collected. Values are means for five rats, with standard errors represented by vertical bars. ${ }^{a, b, c, d, e}$ Mean values with unlike letters were significantly different ( $P<0.05$; one-way ANOVA followed by Tukey's multiple-comparison tests). 
Biotin. Frozen liver samples, about $0.5 \mathrm{~g}$, were thawed,

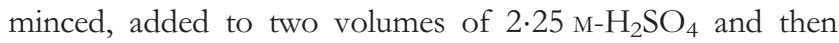
homogenised in a blender. The suspension was autoclaved at $121^{\circ} \mathrm{C}$ for $1 \mathrm{~h}$ to convert bound biotin to the free form of biotin. After cooling, the suspension was centrifuged at $10000 \mathrm{~g}$ for $10 \mathrm{~min}$ at $4^{\circ} \mathrm{C}$. The supernatant was used for measuring biotin levels ${ }^{(39)}$.

\section{Statistical analyses}

Statistical significance was determined by one-way ANOVA followed by Tukey's multiple comparison tests. $P<0.05$ was considered significant. All statistical analyses were undertaken using GraphPad Prism version 5.0 (GraphPad).

\section{Results}

Effects of feeding vitamin-free diet on food intake and gain in body weight

Male Wistar rats (aged 7 weeks) were fed the vitamin-free diet or the control diet for $5 \mathrm{~d}$. No significant difference was observed in the daily gain in body weight between the control group and the vitamin-free diet group (Fig. 1(A)). No significant difference in daily food intake between the two groups was observed (Fig. 1(B)). Rats fed the vitamin-free diet for $5 \mathrm{~d}$ showed no abnormalities in body appearance.

\section{Effects of feeding vitamin-free diet on the urinary excretion of B-group vitamins}

Urinary excretion of each water-soluble vitamin, except for vitamin $\mathrm{B}_{12}$ and the sum of nicotinamide and its catabolites, decreased steeply upon feeding the vitamin-free diet (Fig. 2). Excreted levels of vitamin $\mathrm{B}_{1}$, vitamin $\mathrm{B}_{2}$, 4-pyridoxic acid (catabolite of vitamin $\mathrm{B}_{6}$ ), pantothenic acid, folate and biotin steeply decreased and approached zero within 1-2 d. Urinary excretion of vitamin $B_{12}$ did not decrease because the main elimination route of vitamin $\mathrm{B}_{12}$ is through the bile duct and not the kidney ${ }^{(40)}$. Urinary excretion of the sum of nicotinamide and its catabolites did not decrease because nicotinamide is biosynthesised from tryptophan in the vitamin-free diet.
(A)

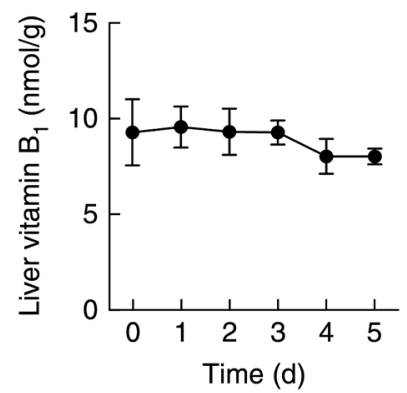

(D)

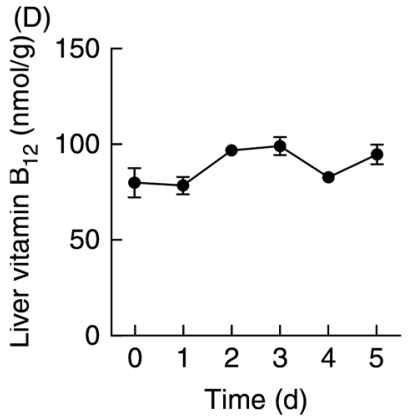

(G)

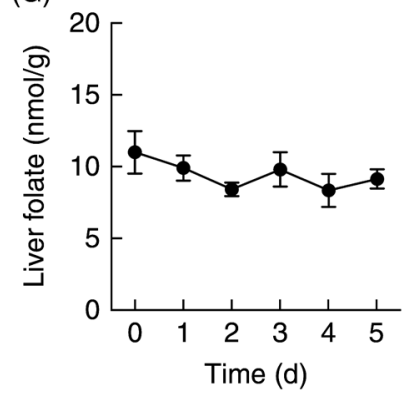

(B)

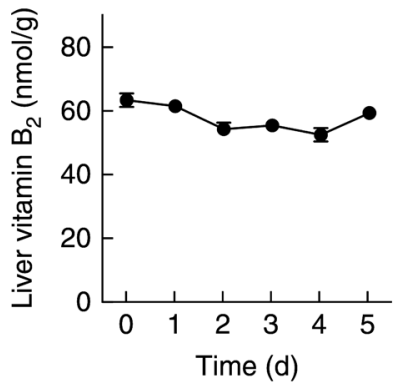

(E)

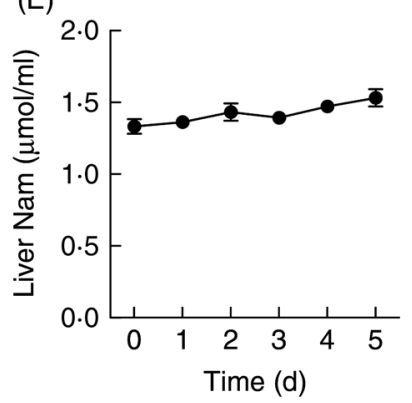

(H)

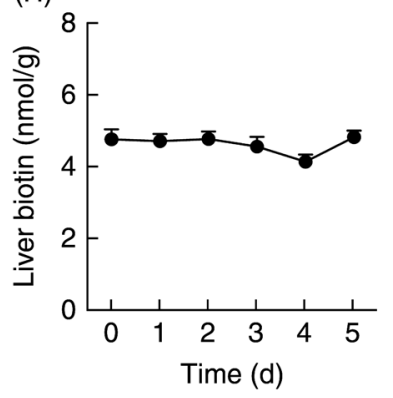

(C)

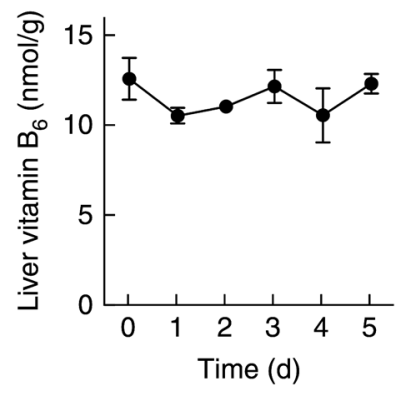

(F)

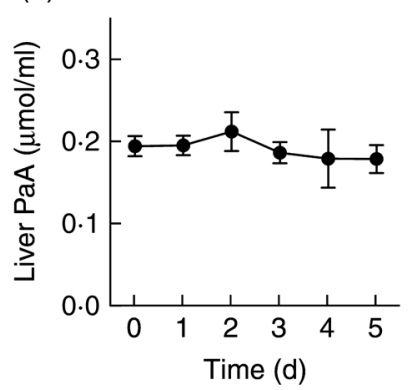

Fig. 4. Changes in the levels of vitamin $B_{1}(A)$, vitamin $B_{2}(B)$, vitamin $B_{6}(C)$, vitamin $B_{12}(D)$, nicotinamide $($ Nam) $(E)$, pantothenic acid $(P a A)(F)$, folate $(G)$ and biotin $(\mathrm{H})$ in the livers of male Wistar rats (aged 7 weeks) fed a vitamin-free diet for $5 \mathrm{~d}$. Rats were killed every day and their livers were removed. Values are means for five rats, with standard errors represented by vertical bars. 
Effects of feeding vitamin-free diet on the concentrations of B-group vitamins in blood and plasma

Nicotinamide was not detected in plasma, even in control rats. Hence, we measured the concentration of nicotinamide in whole blood. Its concentration did not change even when the vitamin-free diet was fed to rats for $5 \mathrm{~d}$. This is because nicotinamide is biosynthesised from tryptophan. With respect to blood, only the concentrations of vitamin $\mathrm{B}_{1}$, pyridoxal phosphate (a coenzyme of vitamin $\mathrm{B}_{6}$ ), and biotin decreased to $15 \%(P<0.0001), 7 \%(P<0.0001)$ and $2 \%(P<$ $0 \cdot 0001)$ on day 5 , respectively, compared with the values at the beginning of the experiment, whereas the reduction in the concentrations of vitamin $\mathrm{B}_{2}$ and folate was not so steep (Fig. 3). The plasma concentrations of vitamin $B_{12}$ and pantothenic acid were not affected.

Effects of feeding vitamin-free diet on liver concentrations of B-group vitamins

The liver contents of all of the B-group vitamins did not decrease even if rats were fed the vitamin-free diet for $5 \mathrm{~d}$ (Fig. 4). The liver samples were not perfused, so a proportion of the levels of vitamins might originate from those found in the blood. However, the concentrations of respective B-group vitamins were much lower in blood samples than in the liver samples (Figs. 3 and 4). Therefore, the blood vitamin levels most probably did not have a significant impact on the vitamin levels observed in the liver samples.

\section{Discussion}

We have reported previously that the urinary excretion of B-group vitamins reflects recent dietary intakes of these vitamins ${ }^{(14-21)}$, and proposed reference values of the urinary levels of B-group vitamins for evaluating nutritional status. This method has been applied to evaluate human nutritional status ${ }^{(21,41)}$. However, the question remains as to whether the urinary excretion of B-group vitamins decreases immediately before animals and human subjects become B-group vitamin insufficient or when they are fed a diet low in vitamins.

In the present study, we investigated the changes in the urinary excretion of B-group vitamins in rats when they were fed a vitamin-free diet. Feeding the vitamin-free diet to growing rats for $5 \mathrm{~d}$ did not affect the food intake, body weight and vitamin concentrations in the liver. These findings indicate that this treatment did not induce B-group vitamin insufficiency.

We measured the plasma B-group vitamins in rats during the feeding of the vitamin-free diet. The concentrations of only three vitamins of the eight B-group vitamins (vitamin $\mathrm{B}_{1}$, pyridoxal phosphate and biotin) were decreased by feeding the vitamin-free diet, but the speed of the decrease was slower and the magnitude was lower than urinary excretion levels. For other B-group vitamins, the concentrations of vitamin $\mathrm{B}_{2}$ and folate were slightly reduced, whereas those of vitamin $B_{12}$, nicotinamide and pantothenic acid were not decreased. These findings suggested that when rats were fed the vitamin- free diet, the concentrations of vitamins are maintained in the body by restriction of the elimination of B-group vitamins into urine. Therefore, the blood samples were not suitable to use for evaluating the nutritional status of B-group vitamins.

As was anticipated, the urinary excretion of B-group vitamins such as vitamin $B_{1}$, vitamin $B_{2}$, vitamin $B_{6}$, pantothenic acid, folate and biotin was steeply decreased by feeding the vitamin-free diet. The decrease was rapid and dramatic (Fig. 2). These findings support our proposal that the urinary excretion of B-group vitamins is a better indicator of B-group vitamin nutritional status than blood concentrations.

In the present study, because sufficient niacin is biosynthesised from tryptophan, the total excretion of nicotinamide and its catabolites was not decreased by feeding the vitamin-free diet. When the rats were fed a tryptophan-limited and niacin-free diet, the urinary excretion of niacin decreased significantly ${ }^{(42)}$. Therefore, the urinary excretion of nicotinamide and its metabolites can be used as an index of niacin nutritional status.

The urinary excretion of vitamin $B_{12}$ was not affected by feeding the vitamin-free diet. This can be explained by the very slow turnover rate of vitamin $\mathrm{B}_{12}$, and the fact that its elimination route is via the bile ${ }^{(40)}$ and not via the kidney. In addition, a large amount of vitamin $B_{12}$ is stored in the liver and kidneys ${ }^{(43)}$.

In conclusion, in animals and human subjects consuming diets low in vitamins, the first potential mechanism to prevent insufficiency of B-group vitamins, except for vitamin $\mathrm{B}_{12}$, is to reduce the urinary elimination of $\mathrm{B}$-group vitamins via the kidney ${ }^{(44)}$. Therefore, the measurement of the urinary B-group vitamins, except for vitamin $B_{12}$, is a suitable method for individual nutritional status assessment. The present data complement our previous proposal that the urinary excretion of B-group vitamins reflects the nutritional status of these vitamins $^{(14-21,41)}$.

\section{Acknowledgements}

This investigation was part of the project 'Studies on the Dietary Reference Intakes for Japanese' (principal investigator, K. S.), which was supported by a Research Grant for Comprehensive Research on Cardiovascular and Life-Style Related Diseases from the Ministry of Health, Labour and Welfare of Japan. K. S., M. S. and T. F. carried out the study design. C. S. and M. S. conducted the experiments. K. S. drafted the manuscript. T. F. provided critical comments on the manuscript. All the authors read and approved the final version of the manuscript. The authors declare that they have no conflicts of interest.

\section{References}

1. Food and Nutrition Board, Institute of Medicine (1998) Dietary Reference Intakes for Thiamine, Riboflavin, Niacin, Vitamin $B_{6}$, Folate, Vitamin $B_{12}$, Pantothenic Acid, Biotin, and Choline. Washington, DC: National Academy Press.

2. Food and Nutrition Board, Institute of Medicine (2000) Dietary Reference Intakes for Vitamin C, Vitamin E, Selenium, and Carotenoids [Institute of Medicine, editor]. Washington, DC: National Academy Press. 
3. Ministry of Health, Labour and Welfare (2009) Dietary Reference Intakes for Japanese, 2010. Tokyo.

4. Boni L, Kiechens L \& Hendrikx A (1980) An evaluation of a modified erythrocyte transketolase assay for assessing thiamin nutritional adequacy. J Nutr Sci Vitaminol 25, 507-514.

5. Sauberlich HE (1984) Newer laboratory methods for assessing nutriture of selected B-complex vitamins. Annu Rev Nutr 4, 377407.

6. Kretsch MJ, Sauberlich HE, Skala JH, et al. (1995) Vitamin B-6 requirement and status assessment: young women fed a depletion diet followed by a plant- or animal-protein diet with graded amounts of vitamin B-6. Am J Clin Nutr 61, 1091-1101.

7. Sauberlich HE, Herman YE, Stevens CO, et al. (1979) Thiamin requirement of the adult human. Am J Clin Nutr 32, 2237-2248.

8. Tillotson JA \& Baker EM (1972) An enzymatic measurement of the riboflavin status in man. Am J Clin Nutr 25, 425-431.

9. O’Neal RM, Johnson OC \& Schaefer AE (1970) Guidelines for classification and interpretation of group blood and urine data collected as part of the National Nutrition Survey. Pediatr Res 4, 103-106.

10. Horwitt MK, Harvey CC, Hills OW, et al. (1950) Correlation of urinary excretion of riboflavin with dietary intake and symptoms of ariboflavinosis. J Nutr 41, 247-264.

11. Goldsmith GA, Sarett HP, Register UD, et al. (1952) Studies of niacin requirement in man. I. Experimental pellagra in subjects on corn diets low in niacin and tryptophan. J Clin Invest 31, 533-542.

12. Fox HM \& Linkswiler H (1961) Pantothenic acid excretion on three levels of intake. J Nutr 75, 451-454.

13. Fry PC, Fox HM \& Tao HG (1976) Metabolic response to a pantothenic acid deficient diet in humans. J Nutr Sci Vitaminol 22, 339-346.

14. Shibata K, Fukuwatari T, Ohta M, et al. (2005) Values of watersoluble vitamins in blood and urine of Japanese young men and women consuming a semi-purified diet based on the Japanese Dietary Reference Intakes. J Nutr Sci Vitaminol 51, 319-328.

15. Fukuwatari T \& Shibata K (2008) Urinary water-soluble vitamins and their metabolite contents as nutritional markers for evaluating vitamin intakes in young Japanese women. J Nutr Sci Vitaminol 54, 223-229.

16. Fukuwatari T, Yoshida E, Takahashi K, et al. (2010) Effect of fasting on the urinary excretion of water-soluble vitamins in humans and rats. J Nutr Sci Vitaminol 56, 19-26.

17. Tsuji T, Fukuwatari T, Sasaki S, et al. (2010) Urinary excretion of vitamin $\mathrm{B}_{1}, \mathrm{~B}_{2}, \mathrm{~B}_{6}$, niacin, pantothenic acid, folate, and vitamin $\mathrm{C}$ correlates with dietary intakes of free-living elderly, female Japanese. Nutr Res 30, 171-178.

18. Tsuji T, Fukuwatari T, Sasaki S, et al. (2010) Twenty-four-hour urinary water-soluble vitamins correlate to vitamin intakes in free-living Japanese university students. Eur J Clin Nutr 64, 800-807.

19. Tsuji T, Fukuwatari T, Sasaki S, et al. (2011) Twenty-four-hour urinary water-soluble vitamin levels correlate with their intakes in freeliving Japanese schoolchildren. Public Health Nutr 14, 327-333.

20. Imai E, Tsuji T, Sano M, et al. (2011) Association between 24 $\mathrm{h}$ urinary alpha-tocopherol catabolite, 2,5,7,8-tetramethyl-2(2'carboxyethyl)-6-hydroxychroman (alpha-CEHC) and alphatocopherol intake in intervention and cross-sectional studies. Asia Pac J Clin Nutr 20, 507-513.

21. Shibata K, Fukuwatari T \& Yoshida M (2011) Vitamins and microminerals. Nutr-Assess Treat 28, 143-147.

22. Eissenstat BR, Wyse BW \& Hansen RG (1986) Pantothenic acid status of adolescents. Am J Clin Nutr 44, 931-937.

23. Schster K, Bailey LB, Cerda JJ, et al. (1984) Urinary 4-pyridoxic acid excretion in 24-hour versus random urine samples as a measurement of vitamin $\mathrm{B}_{6}$ status in humans. Am J Clin Nutr 39, 466-470.
24. Wolfe JM, Bailey LB, Herrlinger-Garcia K, et al. (2003) Folate catabolite excretion is responsive to changes in dietary folate intake in elderly women. Am J Clin Nutr 77, 919-923.

25. Tasevska N, Runswick SA, McTaggart A, et al. (2007) Twenty-fourhour urinary thiamine as a biomarker for the assessment of thiamine intake. Eur J Clin Nutr 62, 1139-1147.

26. Chang SJ, Hsiao LJ, Lee YC, et al. (2007) Vitamin $B_{6}$ status assessment in relation to dietary intake in high school students aged 16-18 years. Br J Nutr 97, 764-769.

27. Kim HA \& Lim HS (2008) Dietary folate intake, blood folate status, and urinary folate catabolite excretion in Korean women of childbearing age. J Nutr Sci Vitaminol 54, 291-297.

28. Reeves PG (1997) Components of the AIN-93 diets as improvements in the AIN-76A diet. J Nutr 127, 838S-841S.

29. Pullman ME \& Colowick SP (1954) Preparation of 2- and 6-pyridones of $N^{1}$-methylnicotinamide. J Biol Chem 206, 121-127.

30. Shibata K, Kawada T \& Iwai K (1988) Simultaneous microdetermination of nicotinamide and its major metabolites, $N^{1}$-methyl-2-pyridone-5-carboxamide and $N^{1}$-methyl-3-pyridone4-carboxamide, by high-performance liquid chromatography. J Chromatogr 424, 23-28.

31. Fukuwatari T, Wada H \& Shibata K (2008) Age-related alterations of B-group vitamin contents in urine, blood and liver from rats. J Nutr Sci Vitaminol 54, 357-362.

32. Gregory JF III \& Kirk JR (1979) Determination of urinary 4-pyridoxic acid using high performance liquid chromatography. Am J Clin Nutr 32, 879-883.

33. Fukuwatari T, Suzuura C, Sasaki R, et al. (2004) Action site of bisphenol $\mathrm{A}$ as metabolic disruptor lies in the tryptophannicotinamide conversion pathway. J Food Hyg Soc Jpn 45, 231-238.

34. Ohkawa H, Ohishi N \& Yagi K (1982) A simple method for microdetermination of flavin in human serum and whole blood by highperformance liquid chromatography. Biochem Int 4, 1871-1894.

35. AOAC International (1995) Official Methods of Analysis, 16th ed. Arlington, VA: AOAC International.

36. Watanabe F, Abe K, Katsura H, et al. (1998) Biological activity of hydroxo-vitamin $\mathrm{B}_{12}$ degradation product formed during microwave heating. J Agric Food Chem 46, 5177-5180.

37. Skeggs H \& Wright LD (1944) The use of Lactobacillus arabinosus in the microbiological determination of pantothenic acid. J Biol Chem 156, 21-26.

38. Aiso K \& Tamura T (1998) Trienzyme treatment for food folate analysis. Optimal $\mathrm{pH}$ and incubation time for $\alpha$-amylase and protease treatment. J Nutr Sci Vitaminol 44, 361-370.

39. Fukui T, Iinuma K, Oizumi J, et al. (1994) Agar plate method using Lactobacillus plantarum for biotin determination in serum and urine. J Nutr Sci Vitaminol 40, 491-498.

40. Shinton NK (1972) Vitamin $\mathrm{B}_{12}$ and folate metabolism. Br Med J i, 556-559.

41. Fukuwatari T \& Shibata K (2012) Urinary water-soluble vitamins as nutritional biomarker to estimate their intake. In Biomarker [T Khan, editor]. Rijeka, Croatia: In'Tech.

42. Shibata K, Mitsue S \& Fukuwatari T (2012) The association between the intakes of B-group vitamins and the contents of those vitamins in the body and the urine. Vitamins 86, 303-308.

43. Shibata K, Shimada H \& Kondo T (1996) Effects of feeding tryptophan-limiting diets on the conversion ratio of tryptophan to niacin in rats. Biosci Biotechnol Biochem 60, 1660-1666.

44. Shibata K \& Matsuo H (1989) Effects of gradually increasing levels of nicotinamide in a niacin-free and tryptophan-limited diet on the blood NAD levels and the urinary excretion of nicotinamide metabolites in rats. Agric Biol Chem 53, 1333-1336. 